\title{
BREAKFAST HABITS AND NUTRIENT ADEQUACY LEVEL OF SNACKS IS CORRELATED WITH NUTRITION STATUS AMONG ADOLESCENT IN SMPN 1 TUBAN
}

\author{
Chandramanda Dewi Damara $^{1^{*}}$, Lailatul Muniroh ${ }^{1}$ \\ ${ }^{1}$ Health Nutrition Department, Faculty of Public Health, Universitas Airlangga, Indonesia \\ *E-mail: Chandramanda.cd@gmail.com
}

\begin{abstract}
Adolescent often skip breakfast, so snacks are usually used as substitute for breakfast at school. Some snacks have unbalanced nutrient content. An imbalance in nutrient intake can affect nutritional status of adolescents. The purpose of this study was to analyze correlation between breakfast habits and nutrition adequacy level of snack with nutritional status of adolescents. The study design used in this study was cross sectional. The sampling technique was proportional random sampling with total sample of 77 students. Data on breakfast habits were obtained through questionnaires, while data on the adequacy level of snacks intake was obtained through $2 \times 24$ hours food recall. The correlation test used was spearman correlation. The results showed that there were correlation between breakfast habits, the adequacy level energy, protein, fat, and carbohydrate of snacks with nutritional status. Adolescent with poor breakfast habits and high adequacy of nutritional levels of snacks tend to have more obesity nutritional status.
\end{abstract}

Keywords: breakfast habits, nutrient adequacy level, nutritional statu, snack

\section{INTRODUCTION}

Adolescence is a period of biological, social and cognitive changes. (WHO, 2015). Adolescents undergo physical changes with varying duration. Nutritious intake is needed by adolescents to increase physical growth and body development. An unbalanced nutritional intake will lead to over or under nutritional status (Adriani, 2012).

Nutritional status in early adolescence must be considered in order to achieve optimal nutritional status to support adolescent growth in the future. Indicator in measuring nutritional status in 13-15 years age group use the results of anthropometric assessments of body weight and height, which are then displayed in body mass index according to age (BMI / U) (Balitbangkes, 2014). Based on the 2018 Basic Health Research data related to nutritional status in 13-15 years age group, it shows an increase in prevalence of overnutrition and obesity. Nationally, in 2013 over nutrition and obesity in 13-15 years age group showed prevalence of $10.8 \%$. In 2018, over nutrition and obesity in 13-15 years age group increased to $16 \%$. A similar increase also occurred in East Java Province, in 2013 over nutrition and obesity in 1315 years age group showed prevalence of $11.9 \%$ and increased to $19.3 \%$ in 2018 .
Good nutritional intake in adolescence is needed to replace malnutrition experienced during childhood and is needed to meet physical growth. (WHO, 2015). Adolescents are prone to change in behavior and lifestyle, especially changes in eating behavior. Irregular eating patterns are often carried out without paying attention to nutritional balance (Adriani, 2012). One of the causes of children being overweight is their habit of not eating breakfast which leads to an increase in frequency of consumption of snack foods that are high in calories, sugar and fat (Steiner, 2012). In addition, children who are accustomed to not having breakfast and not being balanced with intake increment will be at risk of malnutrition. The nutritional status of adolescents who usually eat breakfast are better than those who skip breakfast. Adolescents who have good breakfast consumption habits consume fewer calories in a day and are less likely to be obese (Rampersaud, 2005).

Adolescents are very difficult to find time to sit down to eat and prefer to skip meals or just snacking (Khan, 2009). Energy fulfillment of adolescents while at school are obtained by consuming snack food from stall, canteen, cafeteria, and snacks sold by mobile trader around school environment (BPOM, 2013). Street food is a form 
of food or drink that is served by street vendor for sale in public place and can be consumed directly by buyer. (Food and Agricultural Organization, 2009). School age children have a tendency to eat meal or snack according to what they want. Other factors that can affect include environment, pocket money, peers, and parents (More, 2014). Results of calculating calorie intake in adolescents show that $43 \%$ of calories are obtained only from sugar addition in snack foods (Khan, 2009). The more variety of snack foods sold by traders will encourage the habit of street food consumption for school children, especially during school break hours.

According to Basic Health Research 2013, the prevalence of obesity in 13-15 years age group in Tuban district exceeds provincial prevalence of $8.9 \%$ and national prevalence of $8.3 \%$. State Junior High School 1 Tuban is one of school located in East Java. The location of school, which is right in the middle of the city, makes it easier for students to access street food sold by local traders. Based on the results of preliminary study conducted to determine children's snack consumption, it is known that $68.8 \%$ students prefer to buy snack on roadside, stall, and school canteen rather than bringing lunch from home, $65.2 \%$ of teenagers prefer to eat fried foods such as rolled omelettes, pentol and others, $55.1 \%$ of adolescents consume drinks with flavor additives more often, and $63.3 \%$ of adolescents do not read the nutritional content on packaging label when buying snack food. Based on the explanation of these identified problem that has been mentioned, researcher conducted a study on the relationship between breakfast habits and the level of nutritional adequacy of snack with nutritional status of adolescents at SMPN 1 Tuban.

\section{METHOD}

Study design used in this study was cross sectional. Population in this study were students of SMPN 1 Tuban with a total of 380 students. The chosen subjects were students of class VII and VIII of SMPN 1 Tuban. Based on Lemeshow formula, the subjects were 77 students (Lemeshow, 1997). Technique of taking the subjects in this study was used proportional random sampling until obtained total of class VII 38 students and class VIII 39 students. Students need to met inclusion criteria include not having verbal or speech impairment, not having dietary restrictions and not fasting during study.

Primary data were obtained through anthropometric assessments to determine adolescent nutritional status. Digital scales with an accuracy of $0.1 \mathrm{~kg}$ are used to measure body weight and a microtoise with an accuracy of $0.1 \mathrm{~cm}$ is used for measuring height. Primary data in this study were obtained through interviews with questionnaire on respondent characteristics (age, gender, pocket money for snacks) and parental characteristics (parental education, parental occupation, total parental income). Pocket money for respondent's snacks is categorized into 4 quartiles, which is $\mathrm{K} 1$, $\mathrm{K} 2$, K3, and K4. Parental education is categorized into primary level education (if have completed primary school / junior high school / equivalent), secondary level education (if have completed senior high school / equivalent) and high level education (if have completed diploma / university). Parent's income is classified into 4 quartiles, that is $\mathrm{K} 1, \mathrm{~K} 2, \mathrm{~K} 3$, and $\mathrm{K} 4$. Breakfast habits data were obtained through interviews with a questionnaire. Breakfast habits are grouped into two categories, that is good breakfast habits and poor breakfast habits. Respondents were entered category of good breakfast habits if they meet three criteria, namely breakfast every day ( $7 \mathrm{x} /$ week), breakfast before 09.00 , and breakfast energy intake $>15 \%$ RDA (Soetardjo, 2011; Hardinsyah, 2012). If one of these three criteria cannot be met, respondent is categorized as having poor breakfast habit. The level of nutritional adequacy (energy, protein, fat, and carbohydrates) of snack food was obtained through a $2 \times 24$ hours food recall interview. The application used to convert the interview results is Nutrisurvey, after that the results are compared with nutritional adequacy rate (RDA). The level of adequacy is divided into three, that is low $(<80 \%$ RDA), moderate ( $80 \%-100 \%$ RDA), and high ( $>$ $100 \%$ RDA). Determination of nutritional status in adolescents using BMI / Age indicator. The nutritional status of BMI / Age was categorized into severe undernutrition (<-3 SD), undernutrition ( $-3 \mathrm{SD}$ to $<2 \mathrm{SD})$, normal (-2 SD to $1 \mathrm{SD})$, obese $(>1 \mathrm{SD}$ to $2 \mathrm{SD})$, and obesity (>2 SD). 
Test used to find the correlation between breakfast habits and level of nutritional adequacy of snacks with nutritional status was Spearman correlation test. Research ethics was obtained through approval from the Health Research Ethics Commission (KEPK) Faculty of Nursing Universitas Airlangga with Certificate Number 1357-KEPK.

\section{RESULT AND DISCUSSION}

Table 1 shows $46.8 \%$ of respondents were 13 years old. This age group is categorized aas early adolescent who is happy with new things, has the courage to face various risks, has broad interests and is not afraid of being wrong (Direktorat PLP, 2004).

The results of the study based on gender showed that $58.4 \%$ of respondents were female. At the age of 13-15 years, sex differences can affect the respondents nutritional intake needs. This is adjusted with differences in nutritional adequacy rates between men and women. Based on 2019 Indonesian $\mathrm{RDA}$, the nutritional adequacy rate for men is greater if it is equalized to the nutritional adequacy level for women in the same age.

In terms of the amount of pocket money for snacks, more than half of respondents received pocket money for snacks that were in the range of Rp. 5,000 to Rp. 10,000. The amount of pocket money for snacks is one of the many indirect factors that have effect on nutritional status. The amount of pocket money affects the purchasing

Table 1. Respondent Characteristics

\begin{tabular}{lrr}
\hline Respondent Characteristics & n & \% \\
\hline Age & 37 & 46.8 \\
$\quad$ 13 years & 34 & 44.2 \\
14 years & 7 & 9.0 \\
$\quad$ 15 years & & \\
Sex & 32 & 41.6 \\
$\quad$ Male & 45 & 58.4 \\
$\quad$ Female & & \\
Pocket Money for Snacks & 44 & 57.1 \\
$\quad$ Rp. $5.000-10.000$ & 23 & 29.9 \\
$\quad>$ Rp. $10.000-15.000$ & 8 & 10.4 \\
$\quad>$ Rp. $15.000-20.000$ & 2 & 2.6 \\
$\quad$ > Rp. $20.000-25.000$ &
\end{tabular}

power of respondents towards various snack choices (Rosyidah, 2015).

\section{Parent Characteristics}

Based on Table 2, more than half of respondent's parents have education level in the middle category, that is $57.1 \%$. Parents with a higher level of education have a high level of concern for the quality and nutritional content of served food, so that the nutritional needs of family can be fulfilled properly (Permaesih, 2005).

The largest respondent's total family income is included in the 2nd quartile category with an income range from Rp. 2,500,000 to less than Rp. $4,000,000$. As much as $79.2 \%$ of respondents have an income level that has reached even higher when compared to the district minimum wage in Tuban for 2019 of Rp. 2,233,641.85. The amount of family income can influence family consumption patterns. Sufficient family income can increase the allocation of daily food purchases, so that needs can be fulfilled in terms of both quantity and quality.

\section{Breakfast Habits}

Table 3 shows that almost half of the respondents had breakfast in the category always ( $7 \mathrm{x} /$ week), that is $46.8 \%$. The less frequent

Table 2. Parent Characteristics

\begin{tabular}{lrr}
\hline \multicolumn{1}{c}{ Parent Characteristics } & n & \% \\
\hline Father Education & & \\
$\quad$ Primary Level & 9 & 11.7 \\
$\quad$ Secondary Level & 44 & 57.1 \\
$\quad$ High Level & 24 & 31.2 \\
Mother Education & & \\
$\quad$ Primary Level & 7 & 9.1 \\
$\quad$ Secondary Level & 44 & 57.1 \\
$\quad$ High Level & 26 & 33.8 \\
Parents Total Income & & \\
$\quad<$ Rp. 2.500.000 & 16 & 20.8 \\
$\quad$ Rp. 2.500.000 - <Rp. 4.000.000 & 22 & 28.6 \\
$\quad$ Rp. 4.000.000 - $<$ Rp. 7.000.000 & 18 & 23.4 \\
$\quad$ Rp. 7.000.000 & 21 & 27.2 \\
Income Level & & \\
$\quad<$ UMK Tuban & 16 & 20.8 \\
$\quad \geq$ UMK Tuban & 61 & 79.2 \\
\hline
\end{tabular}


Table 3. Breakfast Habit Criteria

\begin{tabular}{lcc}
\hline \multicolumn{1}{c}{ Criteria } & n & \% \\
\hline $\begin{array}{l}\text { Breakfast Habit Criteria } \\
\text { Frequency }\end{array}$ & & \\
$\quad$ Rarely (<3x/week) & 31 & 40.2 \\
$\quad$ Sometimes (4-6x/week) & 10 & 13.0 \\
$\quad$ Always (7x/week) & 36 & 46.8 \\
Breakfast Time & & \\
$\quad<09.00$ am & 36 & 46.8 \\
$\quad \geq 09.00$ am & 41 & 53.2 \\
Energy Intake & & \\
$\quad<15 \%$ RDA & 40 & 51.9 \\
$\quad \geq 15 \%$ RDA & 37 & 48.1 \\
Breakfast Habit Category & & \\
$\quad$ Good & 27 & 35.1 \\
$\quad$ Poor & 50 & 64.9 \\
\hline
\end{tabular}

breakfast, the greater the increase in nutritional status (Watanabe, 2014). This is in line with research of Kral et al (2011), frequency of breakfast if done regularly will not lead to excess food consumption at the next meal.

Breakfast is food consumption that is done before $09.00 \mathrm{am}$. based on the results of the study, $53.2 \%$ of respondents consumed breakfast at $\geq$ $09.00 \mathrm{am}$. This habit doesn't included into category of good breakfast habits. Breakfast time limits are required to collect data regarding breakfast consumption (Borton et al. 2005).

A healthy breakfast is recommended to meet around $15-30 \%$ of RDA. The results showed that more than half of respondents had energy intake $<15 \% \mathrm{RDA}$, that is $51.9 \%$. Foods that are consumed to replace the unmet energy adequacy usually have higher energy density, simple carbohydrates and have higher fats (Nurul, 2015; Kant, 2005).

In table 3 , it is found that there are $64.9 \%$ respondents categorized as poor breakfast habits, this occurs due to the three criteria did not fulfilled. Respondents who have habit of having breakfast for 7 times / week do not all meet energy intake needs of more than $15 \%$ RDA. In addition, respondents whose breakfast intake was sufficient (> 15\% RDA), not all ate breakfast before 09.00. Based on the results of in-depth interview, it was found that the reasons respondents missed breakfast because not lust or not hungry, fear of being late or late, not having time to cook, and fear of stomach
Table 4. Adequacy Nutrients Level of Respondent's Snack

\begin{tabular}{lll}
\hline \multicolumn{1}{c}{ Nutrient Adequacy } & n & \% \\
\hline Energy & & \\
Low & 28 & 36.4 \\
Moderate & 32 & 41.6 \\
$\quad$ High & 17 & 22.1 \\
Protein & & \\
$\quad$ Low & 21 & 27.3 \\
$\quad$ Moderate & 19 & 24.7 \\
$\quad$ High & 37 & 48.1 \\
Fat & & \\
Low & 16 & 20.8 \\
Moderate & 28 & 36.4 \\
High & 33 & 42.9 \\
Carbohydrate & & \\
$\quad$ Low & 19 & 24.7 \\
$\quad$ Moderate & 26 & 33.8 \\
High & 32 & 41.6 \\
\hline
\end{tabular}

pain. The usual solutions when skipping breakfast include buying snacks or packaged rice in the school canteen. In addition, respondents usually bring milk or bread from home.

\section{Adequacy Nutrition Level of Snack}

The nutritional adequacy level of snack is presented in Table 4, showing that $41.6 \%$ of respondents' energy sufficiency level is in the sufficient category. Nearly half of the respondents had excess protein adequacy level that is $48.1 \%$. As much as $42.91 \%$ of respondents has high fat adequacy level. Carbohydrate adequacy level were high in $41.6 \%$ respondents. Snacks that contain high fat can contribute to increase the risk of overweight or obesity in children (Steiner, 2012). Excess consumption of street food can cause a decrease in appetite. Low and long-lasting appetite can affect nutritional status (Kelishadi, et al. 2017).

\section{Variable Correlation}

Based on Table 5, it can be seen the correlation between breakfast habits and nutritional status with a p-value of 0.000 . The correlation value of this relationship is negative, which shows the opposite direction of the relationship, the is the less good the breakfast habit, the higher the nutritional status. 
In this study, it was found that respondents with nutritional status were lean (2.6\%), fat (14.4\%) and obese $(12.9 \%)$ were categorized as having poor breakfast habits.

Breakfast habit is one factor that can affect nutritional status of adolescents. Breakfast is very important to be eaten as a supply of fuel for nutritional needs in the morning. The habit of skipping breakfast can be a risk factor for health problems. The disadvantages of leaving breakfast include reducing cognitive function in children, reducing children's motivation and enthusiasm for activities, deficiency of macro and micro nutrient which can have a negative effect on physical, mental and health condition (Mhurchu, et al., 2010). The habit of leaving breakfast can be one of the causes for the body to experience nutritional deficiencies that cannot be replaced through other meal times (Rampersaud, 2005). Body lacks glucose as a result of skipping breakfast so that body breaks down energy supplies from fat tissue (Chitra, 2007). If this happens for a long time and continues to process it can result to malnutrition.
Based on Table 5, there is a correlation between level of energy adequacy $(\mathrm{p}=$ $0.000)$, protein $(p=0.001)$ fat $(p=0.000)$, and carbohydrates $(\mathrm{p}=0.000)$ of snack with nutritional status. The correlation value of this relationship is positive, which shows the direction of an unidirectional relationship, that is the higher the level of energy, protein, fat and carbohydrates adequacy from snack food, the higher the nutritional status. In line with research that has been conducted, a correlation was found between fat content of snack and nutritional status (Dini, 2017; Nuryani, 2018). Snack intake is an alternative to fulfill nutrition for individuals who have limited main food consumption and have not met RDA (Syafitri, 2009). Consumption of snack foods that are high in fat and have a high energy density (such as chocolate, donuts, mini terang bulan, martabak, egg rolls, brains, cireng, etc.) causes children not to feel full quickly so it tends to increase the amount of consumption which ultimately has an impact on nutritional status (Jannah, 2017).

Tabel 5. Variable Correlation

\begin{tabular}{|c|c|c|c|c|c|c|c|c|c|c|c|c|}
\hline \multirow{3}{*}{ Variable } & \multicolumn{8}{|c|}{ Nutritional Status } & \multirow{2}{*}{\multicolumn{2}{|c|}{ Total }} & \multirow{3}{*}{ p-value } & \multirow{3}{*}{$\mathbf{r}$} \\
\hline & \multicolumn{2}{|c|}{ Underweight } & \multicolumn{2}{|c|}{ Normal } & \multicolumn{2}{|c|}{ Overweight } & \multicolumn{2}{|c|}{ Obese } & & & & \\
\hline & $\mathbf{n}$ & $\%$ & $\mathbf{n}$ & $\%$ & $\mathbf{n}$ & $\%$ & $\mathbf{n}$ & $\%$ & $\mathbf{n}$ & $\%$ & & \\
\hline \multicolumn{13}{|l|}{ Breakfast Habits } \\
\hline Good & 0 & 0.0 & 27 & 35.1 & 0 & 0.0 & 0 & 0.0 & 27 & 35.1 & \multirow{2}{*}{$0.000 *$} & \multirow{2}{*}{-0.390} \\
\hline Poor & 2 & 2.6 & 27 & 35.1 & 11 & 14.3 & 10 & 13.0 & 50 & 64.9 & & \\
\hline \multicolumn{13}{|c|}{ Adequacy Level Energy } \\
\hline Low & 2 & 2.6 & 17 & 22.0 & 1 & 1.3 & 0 & 0.0 & 20 & 25.9 & \multirow{3}{*}{$0.000^{*}$} & \multirow{3}{*}{0.594} \\
\hline Moderate & 0 & 0.0 & 36 & 46.8 & 10 & 13.0 & 0 & 0.0 & 46 & 59.8 & & \\
\hline High & 0 & 0.0 & 1 & 1.3 & 0 & 0.0 & 10 & 13.0 & 11 & 14.3 & & \\
\hline \multicolumn{13}{|l|}{ Protein } \\
\hline Low & 2 & 2.6 & 33 & 42.9 & 5 & 6.5 & 0 & 0.0 & 40 & 52.0 & \multirow{3}{*}{$0.001 *$} & \multirow{3}{*}{0.362} \\
\hline Moderate & 0 & 0.0 & 19 & 24.6 & 6 & 7.8 & 0 & 0.0 & 25 & 32.4 & & \\
\hline High & 0 & 0.0 & 2 & 2.6 & 0 & 0.0 & 10 & 13.0 & 12 & 15.6 & & \\
\hline \multicolumn{13}{|l|}{ Fat } \\
\hline Low & 2 & 2.6 & 17 & 22.1 & 0 & 0.0 & 0 & 0.0 & 19 & 24.7 & \multirow{3}{*}{$0.000 *$} & \multirow{3}{*}{0.464} \\
\hline Moderate & 0 & 0.0 & 34 & 44.1 & 11 & 14.3 & 0 & 0.0 & 45 & 58.4 & & \\
\hline High & 0 & 0.0 & 3 & 3.9 & 0 & 0.0 & 10 & 13.0 & 13 & 16.9 & & \\
\hline \multicolumn{13}{|l|}{ Carbohydrate } \\
\hline Low & 2 & 2.6 & 24 & 31.2 & 3 & 3.9 & 0 & 0.0 & 29 & 37.7 & \multirow{3}{*}{$0.000 *$} & \multirow{3}{*}{0.587} \\
\hline Moderate & 0 & 0.0 & 30 & 38.9 & 8 & 10.4 & 2 & 2.6 & 40 & 51.9 & & \\
\hline High & 0 & 0.0 & 0 & 0.0 & 0 & 0.0 & 8 & 10.4 & 8 & 10.4 & & \\
\hline
\end{tabular}


Based on table 5, it is found $12.9 \%$ of respondents that have obese status, have poor breakfast habits, but the level of energy, protein and fat in their snacks included in excess category. This shows that respondents with obesity nutritional status consume excess snack food due to poor breakfast habits. In line with the findings of Mariza, et al. (2013), there is a correlation between breakfast habits and snack habits in children. The more often children skip breakfast, 1,5 times greater risk of children for taking snacks. In addition, it was found that there was a correlation between the habit of consuming street food and nutritional status. The habit of consuming street food has a seven-fold higher risk of experiencing an increase in nutritional status which leads to overnutrition and obesity.

\section{CONCLUSION}

Breakfast habit and nutritional adequacy level of snack were related to nutritional status. Respondents with poor breakfast habits and high adequate nutrition levels of snack were tend to have obese nutritional status. It is expected that respondents can improve the quality of their breakfast habits by fulfilling the nutritional intake of $15-30 \%$ of daily needs and consuming breakfast every day before $9 \mathrm{am}$. With the fulfillment of nutritional needs of breakfast, the intake of street food is reduced so that it can achieve optimal nutritional status.

\section{ACKNOWLEDGEMENT}

Author would like to thank SMPN 1 Tuban for allow to conduct research at SMPN 1 Tuban, grade VII and VIII students who volunteered to become respondents, counseling teachers who had taken the time to accompany during data collection.

\section{REFERENCES}

Adriani, M. \& Bambang, W. (2012). Peranan gizi dalam siklus kehidupan. Kencana Prenada Media Group. Jakarta

Kementerian Kesehatan RI. (2019). Angka kecukupan gizi yang dianjurkan untuk masyarakat Indonesia. Lampiran Peraturan Menteri Kesehatan Republik Indonesia Nomor 28 Tahun 2019.
Balitbangkes RI. (2014). Riset Kesehatan Dasar Tahun 2013. Jakarta: Kementrian Kesehatan RI.

Balitbangkes RI. (2019). Riset Kesehatan Dasar Tahun 2018. Jakarta: Kementrian Kesehatan RI.

BPOM. (2013). Pedoman pangan jajanan anak sekolah untuk pencapaian gizi seimbang. Direktorat Standardisasi Produk Pangan, Deputi Bidang Pengawasan Keamanan Pangan dan Bahan Berbahaya, Badan Pengawas Obat dan Makanan RI.

Chitra, U. \& Reddy, C. (2007). The role of breakfast in nutrient intake of urban school children. Public Health Nutr. 10(1):55-8. doi: 10.1017/ S1368980007219640

Direktorat Pendidikan Lanjutan Pertama. (2004). Pedoman Diagnostik Potensi Peserta Didik. Jakarta : Depdiknas.

Food and Agricultural Organization. (2009). Food safety and quality (Street food). Retrieved from http://www.fao.org/food/food-safety-quality/az-index/street-foods $0 /$ en/.

Hardinsyah \& Aries, M. (2012). Jenis pangan sarapan dan perannya dalam asupan gizi harian anak usia 6-12 tahun di Indonesia. Jurnal Gizi dan Pangan 7(2) : 89-96. doi: 10.25182/ jgp.2012.7.2.89-96

Khan, L. K. (2009). Recommended community strategies and measurements to prevent obesity in the United States. Morbidity and Mortality Weekly Report 2009; 58 (RR07) : 1-26.

Kral, T.V.E., Whiteford, L.M., Heo, M., \& Faith, M.S. (2011). Effects of eating breakfast compared with skipping breakfast on ratings of appetite and intake at subsequent meals in 8- to 10-y-old children. Am J Clin Nutr 93(2) : 284-91. doi: 10.3945/ajen.110.000505

Kelishadi, R., Mozafarian, N., Qorbani, M., Motlagh, ME., Safri, S., Ardalam, G., ... Heshmat, R. (2017). Is snack consumption associated with meal skipping children and adolescent? TheCASPIAN IV Study. PubMed. 22(2):321-32. doi: 10.1007/s40519-017-0370-4

Lemeshow, S., Hosmer, D.W., Klar, J. \& Lwanga, S.K. (1997). Besar Sampel Dalam Penelitian Kesehatan. Yogyakarta : Gajahmada University Press.

Mariza, Y. \& Kusumastuti, A. (2013). Hubungan antara kebiasaan sarapan dan kebiasaan jajan dengan status gizi anak sekolah dasar Di Kecamatan Pedurungan Kota Semarang. Journal Of Nutrition College. 2(1): 207-213. doi: https://doi.org/10.14710/jnc.v2i1.2108 
More, J. Diterjemahkan Oleh Soetjipto, M. (2014). Gizi Bayi, Anak, Dan Remaja. Yogyakarta : Pustaka Pelajar.

Mhurchu, C.N., Gorton, D., Turley, M., Jiang, Y., Michie, J., Maddison, R., \& Hattie, J. (2010). Effects of a free school breakfast programme on school attendance, achievement, psychosocial function, and nutrition: a stepped wedge cluster randomisedtrial. British Medical Journal Public Health. 10: 738. Retrieved from https://bmcpublichealth.biomedcentral.com/ articles/10.1186/1471-2458-10-738

Permaesih, D. \& Herman, S. (2005). Faktor-faktor yang mempengaruhi anemia pada remaja. Buletin Penelitian Kesehatan 33 (4). Retrieved from http://ejournal.litbang.depkes.go.id/index. php/BPK/article/download/219/294

Rampersaud, G., Pereira, M., Girard, B., Adams, J., \& Metzl, J. (2005). Breakfast habits, nutritional status, body weight, and academic performance in children and adolescents. J Am Diet Assoc. (5):743-60. doi: 10.1016/j.jada.2005.02.007

Rosyidah, Z. \& Andrias, D.R. (2015). Jumlah uang saku dan kebiasaan melewatkan sarapan berhubungan dengan status gizi lebih anak sekolah dasar. Media Gizi Indonesia. 10 (1). Retrieved from https://e-journal.unair.ac.id/ MGI/article/view/3114

Sholikah, A., Ristiana, E.R., \& Yuniastuti, A. (2017). Faktor - faktor yang berhubungan dengan status gizi balita di pedesaan dan perkotaan. Public Health Perspective Journal. 2(1) : $9-18$. Retrieved from https://journal.unnes.ac.id/nju/ index.php/phpj/article/view/10993

Soetardjo, S. (2011). Gizi Seimbang dalam Daur Kehidupan. Jakarta: PT. Gramedia Pustakan Utama.

Watanabe, Y., Saito, I., Henmi, I., Yoshimura, K., Maruyama, K., Yamauchi, K., ... Asada, Y. (2014). Skipping breakfast is correlated with obesity. J Rural Med JRM / Japanese Assoc Rural Med. 9(2) : 51- 8. doi: 10.2185/ jrm.2887

World Health Organization (WHO), 2015. Adolescent Development: Topics at Glance Retrieved from http://www.who.int/maternal child_adolescent/ topics/adolescence/dev/ en/\#. 